\title{
Effective selection of countries in sub-Saharan Africa for new market entry by independent wind power producers
}

\author{
Carsten Lausberg ${ }^{1 *}$ (D) , Kathleen Evans ${ }^{2}$ (D), Enelge de Jongh ${ }^{3}$ \\ 1 Campus of Real Estate, Nurtingen-Geislingen University, Geislingen, Germany \\ 2 Department of Construction Economics and Management, University of Cape Town, Cape Town, South Africa \\ 3 Cape Town, South Africa
}

\begin{abstract}
When independent power producers (IPPs) assess new market entry opportunities, subjective decision making can result in an unfavourable outcome. Multi-criteria decision analyses (MCDA) objectify the decision process and help to achieve better results. The aim of this study is to determine and rank the most important criteria for market entry and then determine which selected countries in sub-Saharan Africa are most favourable for wind IPPs. A combination of MCDA methods was used to rank seven countries. Nineteen criteria, identified in the literature reviewed, were included in the analyses. In the first phase of the study an industry expert survey was conducted and the analytical hierarchy process (AHP) was used to rank the criteria in order of importance. In the second phase, a preference ranking organization method for enrichment evaluation (PROMETHEE) was employed to rank the countries from most to least favourable for IPP market entry. The expert survey and AHP showed that political and economic criteria are more important than technical and social criteria. The PROMETHEE model ranked South Africa followed by Ethiopia as the most favourable markets for wind IPPs to enter. These countries have strong natural wind resources but only South Africa offers incentives specifically for on-grid renewable energy. The methods used in this study are not restricted to the wind industry and can be expanded to different technologies and industries to assist with decision making.
\end{abstract}

Keywords: wind energy; market entry; multi-criteria decision analyses (MCDA); analytical hierarchy process (AHP); preference ranking organization method for enrichment evaluation (PROMETHEE)

\footnotetext{
Journal of Energy in Southern Africa 32(4): 28-44

DOI: https://dx.doi.org/10.17159/2413-3051/2021/v32i4a10673

Published by the University of Cape Town ISSN: 2413-3051 https://journals.assaf.org.za/jesa

This work is licensed under a Creative Commons Attribution-ShareAlike 4.0 International Licence

Sponsored by the Department of Science and Innovation 


\section{Introduction and background}

Energy is one of the most important factors for a country's economic and socioeconomic growth (Eggoh et al., 2011). Sub-Saharan Africa (SSA) has significant energy challenges, one of them being the slow rate at which new power generation has been developed and brought online (Bazilian et al., 2012; Deichmann et al., 2011). An additional hindrance to supplying the region with electricity is the poorly developed and maintained grid and substation infrastructure (Eberhard et al., 2008; Brew-Hammond, 2010). Energy access in SSA is not only important for economic growth, but also increases the general quality of life of people by improving their healthcare, education and economic opportunities (Brew-Hammond, 2010; Bazilian et al., 2012; Deichmann et al., 2011; Eberhard and Gratwick, 2011). Research suggests that renewable energy should take centre stage in the drive to increase electricity generation across SSA and it is estimated that by 2040 about half of new generation will come from renewable energy (IEA, 2019; Bazilian et al.; 2012, Deichmann et al., 2011; Suberu et al., 2013). However, there are many imponderables and it may well be that the share of renewable energy will remain modest, as some other researchers believe (Alova et al., 2021). Hydropower is the only renewable energy source that has been rolled out on a large scale in SSA (IEA, 2019; Eberhard et al. 2008; Karekezi, 2002). However, Africa's reliance on hydropower has caused problems because severe droughts have dramatically reduced generation output. This has highlighted the importance of a diversified energy mix, especially expanding wind and solar generation (IEA, 2014). The total wind potential for SSA is estimated to be around $1300 \mathrm{GW}$, more than 14 times the current total installed capacity (IEA, 2014). Wind energy is more restricted and complex to develop than solar energy, but has great potential on the African continent due to its low cost. (IEA, 2016) Overall, wind energy currently has the lowest cost of all types of renewable energy, although that somewhat depends on location and type (onshore/offshore) (IRENA, 2021)

There are many challenges hindering development of renewable energy resources in SSA (Painuly, 2001; Beck and Martinot, 2004). The most common non-financial challenges include grid infrastructure constraints; non-cost reflective tariffs; lack of political will, policies and stability; high levels of corruption; lack of renewable energy knowledge and missing creditworthiness of stateowned utilities that act as the electricity off-takers. Furthermore, there are several risk factors on the plant level, such as the size and the grid connection, which reduce the chances of implementing power plants in general (Alova et al., 2021). Therefore independent power producers (IPPs) can play an im- ortant role in exploiting renewable energy potential in SSA countries. They often take on a pioneering role and open up a country for the industrial use of renewable energies (Steffen et al., 2018). The focus on renewable energy and IPPs is changing the energy sector, shifting investment into the sector from traditional government and international donors to independent companies and banks (Martinot et al., 2002). In recent years, the realisation chances of IPPs have improved (Alova et al., 2021). IPPs, however, cannot enter every market because of the high costs, risks and low success rates associated with procurement programmes, forcing them to be selective (Beim and Lévesque, 2006; Gokmenoglu and Alaghemand, 2015; Wijnja, 2014). 'In general, it can be stated that regulatory reliability and support is the key to the long-term deployment of wind power' (WWEA, 2018).

This study aims to determine, assess and rank the most important criteria wind IPPs should consider when evaluating market entry. By using an analytical and more formal decision making process, such as MCDA, and using these ranked criteria to determine which countries in SSA are most favourable for wind IPPs, this ranking will significantly assist in reducing market entry risk. The research involves seven countries, selected to incorporate a broad diversity with regards to the most important decision criteria. It will assist IPPs that specialise in wind energy and that need to evaluate new markets (Nganga and Maruyama, 2015).

\section{Literature review 2.1 Decision analysis methods in renewable energy}

For a long time managerial decision theory claimed that the best alternative from a set of solution alternatives could be found by optimising a single monetary target variable, such as the highest return or the lowest cost. Since this approach was too simplistic for most practical applications, target systems were created that were able to integrate nonmonetary and non-economic goals, such as the market position of a company. The energy sector's decision framework is exemplary for this development: Initially a single criterion (the lowest cost) was sufficient, but the increasing impact on the environment made it necessary to integrate technical, environmental and social factors (Pohekar and Ramachandran, 2004; Painuly, 2001). There are many methods suitable to assess these factors and make informed decisions. The most commonly used methods include cost-benefit analysis, Delphi techniques, strengths, weaknesses, opportunities and threats analysis (SWOT) and multi-criteria decision analysis (MCDA). Table 1 summarises literature reviewed, highlighting the different methods for decision analysis in renewable energy. 
Table 1: Evaluation of decision making methods

\begin{tabular}{|c|c|c|c|c|}
\hline Method & Description & Advantages & Disadvantages & References \\
\hline $\begin{array}{l}\text { Cost-benefit } \\
\text { analysis }\end{array}$ & $\begin{array}{l}\text { Estimates a net pre- } \\
\text { sent value for the cost } \\
\text { and benefits of each } \\
\text { alternative }\end{array}$ & $\begin{array}{l}\text { Easy to compare al- } \\
\text { ternatives with each } \\
\text { other }\end{array}$ & $\begin{array}{l}\text { Assumes a mone- } \\
\text { tary value can be } \\
\text { quantified for all } \\
\text { attributes }\end{array}$ & $\begin{array}{l}\text { Moran \& Sherrington } \\
\text { (2007); Snyder \& } \\
\text { Kaiser (2009); Di- } \\
\text { akloulaki \& Karange- } \\
\text { lis (2007); Wijnja } \\
\text { (2014) }\end{array}$ \\
\hline $\begin{array}{l}\text { Delphi tech- } \\
\text { nique }\end{array}$ & $\begin{array}{l}\text { Gathers information } \\
\text { from experts through } \\
\text { two or more survey } \\
\text { rounds, with the end } \\
\text { goal of reaching gen- } \\
\text { eral consensus }\end{array}$ & $\begin{array}{l}\text { Valuable when there } \\
\text { is limited data to ana- } \\
\text { lyse }\end{array}$ & $\begin{array}{l}\text { Success depends } \\
\text { on the quality of } \\
\text { the participants; } \\
\text { risk of imposing } \\
\text { personal views by } \\
\text { researchers ana- } \\
\text { lysing data }\end{array}$ & $\begin{array}{l}\text { Gordon (1994); } \\
\text { Wijnja (2014); Varho } \\
\text { et al. (2016); Celiktas } \\
\text { \& Kocar (2010); Mur- } \\
\text { ray (1979); Pill } \\
\text { (1971); Tichy (2004); } \\
\text { Welty (1972) }\end{array}$ \\
\hline $\begin{array}{l}\text { SWOT } \\
\text { (Strengths, } \\
\text { weaknesses, } \\
\text { opportunities } \\
\text { and threats) }\end{array}$ & $\begin{array}{l}\text { Evaluates the current } \\
\text { and future strengths } \\
\text { and weaknesses of } \\
\text { the opportunity }\end{array}$ & $\begin{array}{l}\text { Thoroughly evaluates } \\
\text { an opportunity or } \\
\text { market or nation and } \\
\text { identifies shortcom- } \\
\text { ings and problem ar- } \\
\text { eas }\end{array}$ & $\begin{array}{l}\text { Difficult to com- } \\
\text { pare al ternatives } \\
\text { against each other }\end{array}$ & $\begin{array}{l}\text { Terrados et al. } \\
\text { (2007); Markovska et } \\
\text { al. (2009); Chen et al. } \\
(2014)\end{array}$ \\
\hline $\begin{array}{l}\text { Multi-criteria } \\
\text { decision analy- } \\
\text { sis (MCDA) }\end{array}$ & $\begin{array}{l}\text { Various methods } \\
\text { available to firstly } \\
\text { rank criteria and then } \\
\text { to rank alternatives } \\
\text { based on the ranking } \\
\text { of critera }\end{array}$ & $\begin{array}{l}\text { Can handle both qual- } \\
\text { itative and quantative } \\
\text { data; can compare al- } \\
\text { ternatives with each } \\
\text { other }\end{array}$ & $\begin{array}{l}\text { Complex com- } \\
\text { pared to other } \\
\text { methods }\end{array}$ & $\begin{array}{l}\text { Wang et al. (2009); } \\
\text { Wang \& Poh (2014); } \\
\text { Pohekar \& } \\
\text { Ramachandran } \\
\text { (2004); Trotter et al. } \\
\text { (2017) }\end{array}$ \\
\hline
\end{tabular}

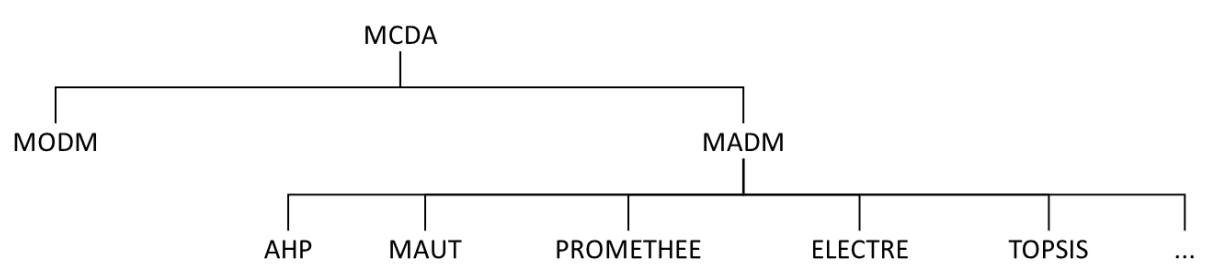

Figure 1: Overview of MCDA methods (based on Taha and Diam, 2013)

To identify the most favourable markets for wind IPPs the countries (decision alternatives) have to be compared with each other using various criteria (economic, technical, environmental and social). Based on the review of the different methods, MCDA is preferred because it ranks the criteria according to importance and has the ability to compare alternatives.

\subsection{Multi-criteria decision analysis methods}

MCDA methods can broadly be classified into multiobjective decision making (MODM) and multi-attribute decision making (MADM). They differ primarily in the variables used and in whether the alternatives are predefined. In MODM, continuous variables are used and the alternatives are not given. The decision problem is to develop alternat- ive solutions and then to find the optimal one. In contrast, MADM uses discrete variables. The alternatives are given, so that the decision problem is to choose the best alternative. Selecting the best market for renewable energy IPPs to enter can therefore be considered under MADM, where each country is evaluated against a set of criteria. The importance of each criterion is usually determined by experts who use data analyses, but also their experience and intuition for this task. The best-known MADM methods include analytical hierarchy process (AHP), multi-attribute utility theory (MAUT), preference ranking organisation method for enrichment evaluation (PROMETHEE), elimination and choice translating reality (ELECTRE) and technique for order preference by similarity to ideal situation (TOPSIS) (see Figure 1). 
There is a wealth of literature on the MCDA method selection problem and, according to Wątróbskia et al. (2019), who offer a complete overview, it can be solved in three ways: benchmarking, multi-criteria methods, and formal or informal structuring of a decision situation. For this paper an informal approach was taken because of the research design. The goal was to find the most favourable countries for wind IPPs in general, independent of any particular wind IPP. Hence, only the criteria relating to the subject of the decision that are presented in the next section could be used, while criteria relating to a specific decision maker's preference had to be left out. The features of the five methods are summarised in Table 2.

Table 2: Evaluation of MCDA methods (expanded and adapted from Wijnja, 2014)

\begin{tabular}{|c|c|c|}
\hline Method & Advantages & Disadvantages \\
\hline AHP & $\begin{array}{l}\text { - Easy to use } \\
\text { - Not as data intensive at MAUT } \\
\text { - Flexible, intuitive \& checks in- } \\
\text { consistencies } \\
\text { - No bias in decision making } \\
\text { - Easy to see importance of each } \\
\text { element } \\
\text { - Can include different data } \\
\text { types }\end{array}$ & $\begin{array}{l}\text { - Additive aggregation is used, so important infor- } \\
\text { mation may be lost } \\
\text { - Unidirectional relationship cannot handle the } \\
\text { complexity of many problems } \\
\text { - Relies on judgements of experts to derive prior- } \\
\text { ity scales } \\
\text { - Interdependence between criteria and alterna- } \\
\text { tives } \\
\text { - Susceptible to rank reversal if alternatives are } \\
\text { added at the end of the process } \\
\text { - Does not deal with uncertainty }\end{array}$ \\
\hline MAUT & $\begin{array}{l}\text { - Takes uncertainty into account } \\
\text { - Easy to see importance of each } \\
\text { element }\end{array}$ & $\begin{array}{l}\text { - Data intensive } \\
\text { - Can be subjective because the preferences of de- } \\
\text { cision maker are incorporated } \\
\text { - Complex method and hard to use }\end{array}$ \\
\hline $\begin{array}{l}\text { PROMETHEE } \\
\text { (outranking } \\
\text { method) }\end{array}$ & $\begin{array}{l}\text { - Can include different data } \\
\text { types } \\
\text { - Easy to use } \\
\text { - Takes uncertainty into account }\end{array}$ & - No weight factor calculation \\
\hline $\begin{array}{l}\text { ELECTRE } \\
\text { (outranking } \\
\text { method) }\end{array}$ & $\begin{array}{l}\text { - Can include different data } \\
\text { types } \\
\text { - Takes uncertainty into account }\end{array}$ & $\begin{array}{l}\text { - No weight factor calculation } \\
\text { - Complex method }\end{array}$ \\
\hline TOPSIS & $\begin{array}{l}\text { - Simple process } \\
\text { - Easy to use } \\
\text { - Number of steps remains the } \\
\text { same regardless of the number } \\
\text { of attributes } \\
\text { - Can include unlimited number } \\
\text { of alternatives and criteria }\end{array}$ & $\begin{array}{l}\text { - Difficult to weigh attributes and keep consistency } \\
\text { of judgement } \\
\text { - Susceptible to rank reversal if alternatives are } \\
\text { added at the end of the process; can remove this } \\
\text { by having a limited number of alternatives to } \\
\text { begin with }\end{array}$ \\
\hline
\end{tabular}

\subsection{Criteria for IPPs to consider when evaluating business opportunities}

After the 1980s the energy sector did not only incurporate economic factors in decision analysis, but also technical, environmental and social factors (Pohekar and Ramachandran, 2004). Numerous studies have reviewed the main- and sub-criteria incorporated into renewable energy decision making, including Wang et al. (2009), Afsordegan et al. (2016), Höfer et al. (2016), Lee et al. (2009), Trotter et al. (2017), and Naicker and Thopil (2019). Not all of these criteria could be used for this study; for instance, several of the criteria suggested by Polatidis et al. (2006) are specific to the decision maker. Other criteria mentioned in the literature were left out because they were beyond the scope of this study; for example, criteria under the country level. On the other hand, additional criteria outside the energy industry should be considered when studying market entry, as illustrated in Beim and Lévesque (2006) who also included, for example, political stability, lack of crime and corruption and gross domestic product growth rate. Therefore, studies highlighting criteria for international busi- 
ness opportunities were also reviewed, including Cheng et al. (2011), Mekking (2008), Swoboda et al. (2007), and Beim and Lévesque (2006). Criteria for this study are based on Wijnja (2014), expanded to include additional criteria which are also considered important for wind IPP market entry.

Table 3 sets out the criteria and sub-criteria that will be used in this study. They are not taken from a single study, but are a combination of criteria used in several studies which researched either renewable energy decision making, wind farm selection or international business opportunities. Although the criteria are gathered from various studies, the base was taken from Wijnja (2014). References are also given for studies in which these criteria were applied.

Table 3: Criteria used for this study

\begin{tabular}{|c|c|c|c|}
\hline Category & Criteria & Sub-criteria & References \\
\hline \multirow[t]{4}{*}{ Technical } & Wind climate & Wind resource & Lee et al. (2009) \\
\hline & & Maximum capacity factor & Wijnja (2014) \\
\hline & Electricity & Grid stability & \\
\hline & Grid system & National electrification rate & Wijnja (2014) \\
\hline \multirow[t]{9}{*}{ Economic } & Cost of electricity & Electricity tariff & Wijnja (2014) \\
\hline & & Electricity cost & Wang et al. (2009) \\
\hline & Corporate tax rate & & Wijnja (2014) \\
\hline & Country credit rating & & Swoboda et al. (2007) \\
\hline & Country forex reserve & & \\
\hline & Ease of doing business & & Wijnja (2014) \\
\hline & Market size & $\begin{array}{l}\text { Current generation capacity } \\
\text { Future demand }\end{array}$ & $\begin{array}{l}\text { Beim and Levesque (2006); Wijnja } \\
\text { (2014); }\end{array}$ \\
\hline & & & $\begin{array}{l}\text { Swoboda et al. (2007); Cheng et al. } \\
\text { (2011) }\end{array}$ \\
\hline & $\begin{array}{l}\text { PPA quality (power } \\
\text { purchase agreement) }\end{array}$ & $\begin{array}{l}\text { Payment guarantee } \\
\text { PPA term }\end{array}$ & \\
\hline \multirow[t]{4}{*}{ Political } & Government support & Renewable energy targets & Lee et al. (2009) \\
\hline & & $\begin{array}{l}\text { Incentives (specifically and } \\
\text { exclusively) for on-grid re- } \\
\text { newable energy }\end{array}$ & $\begin{array}{l}\text { Beim and Levesque (2006); Wijnja } \\
\text { (2014); Cheng et al. (2011) }\end{array}$ \\
\hline & Political stablity & $\begin{array}{l}\text { Political risk } \\
\text { Safety in-country }\end{array}$ & $\begin{array}{l}\text { Beim and Levesque (2006); Wijnja } \\
\text { (2014) }\end{array}$ \\
\hline & & & $\begin{array}{l}\text { Mekking (2008); Swoboda et al. } \\
(2007)\end{array}$ \\
\hline Social & Market acceptance & & $\begin{array}{l}\text { Lee et al. (2009); Wang et al. (2009); } \\
\text { Cheng et al. (2011) }\end{array}$ \\
\hline
\end{tabular}

\subsubsection{Technical criteria}

Technical criteria include wind climate and grid system. Wind climate is divided into wind resource and maximum capacity factor. Wind resource is a measure of a country's potential to harvest wind energy, whereas maximum capacity factor is the wind potential of the area with the highest potential for wind energy in the country. The electricity grid system criteria are divided into grid stability and national electrification rate. Grid stability refers to the condition of the grid including the number of interruptions and voltage fluctuations. The electrification rate refers to the degree of households and businesses connected to the grid: the higher the electrification rate, the higher the demand for energy and thus the higher the potential for IPPs.

\subsubsection{Economic criteria}

Economic criteria include cost of electricity, corporate tax rate, credit rating, forex reserve, ease of doing business, market size and power purchase agreement (PPA) quality. Cost of electricity is divided into electricity tariff and electricity cost. Electricity tariff is the estimated national electricity tariff (average for residential, commercial and industrial users) paid by users. Electricity cost refers to the 
average electricity production cost of a country. The higher these tariffs, the more likely itwill be that renewable energy technologies will be cost-competitive. The corporate tax rate is the income tax rate for companies. A lower tax rate will enable companies to keep a greater portion of their revenues. The credit rating is a measure of a country's likelihood for defaulting and hence an indication of the country risk. State utilities are closely linked to the government and therefore, in most instances, the country's credit rating is a reflection of the credit rating of the state-owned utility, which is the 'off-taker' of the electricity generated. The forex reserve links to the country's ability to pay for its needs and liabilities such as PPAs. PPAs are often paid in US dollars or in local currency and linked to the US dollar. An IPP will try to convert to US dollars as soon as possible, as many African countries have depreciating currencies. Ease of doing business is an index created by the World Bank; higher rankings indicate better, usually simpler, regulations for businesses and stronger protections of property rights. The market size is split into current generation capacity and future demand. Current generation capacity refers to the portion of the consumed electricity produced locally. Future demand is the expected growth per year for energy demand. PPA quality is a criterion which was not included in the reviewed studies in Table 3, but can be linked to the ease of profit repatriation criterion used in Beim and Lévesque (2006), because the PPA will guide how the IPP is paid and what provisions are in place to ensure payment. PPA quality is divided into payment guarantee and PPA term. A payment guarantee is offered by the government and assures the IPP that it will be paid even if the utility defaults. PPA term refers to the length of the contract; a longer term means that the project will receive income for a longer period and is thus more attractive for an IPP.

\subsubsection{Political criteria}

Political criteria include government support and political stability. Government support is divided into renewable energy targets and incentives for on-grid renewable energy. Renewable energy targets are published targets either in policies or development frameworks which are specific for renewable energy technologies. Incentives specifically and exclusively for on-grid renewable energy are incentives such as tax benefits that are not applicable to other technologies and industries. If a country has specific targets and incentives for renewable energy it is an indication of the seriousness of the government to make renewable energy a reality and therefore more favourable for IPPs. Political stability can be divided into political risk and safety in-country. Political risk is the risk an investment could suffer as a result of political changes or instability. Safety in-country refers to the safety of personnel working in the country.

\subsubsection{Social criteria}

Social criteria include market acceptance, which is a measure of how well the market adopts renewable energy and supports its implementation.

\section{Methodology}

\subsection{Research approach}

This study aims to rank countries from most to least favourable for wind IPP market entry. Both quantitative and qualitative elements are used, so a mixed methods approach is chosen. It has become standard procedure to use AHP for analysing the structure of the problem and determining the weights of the criteria, and PROMETHEE for the final ranking (see, for example, Ghobadi and Ahmadipari (2018) and $\mathrm{Wu}(2020))$.

The research was conducted in two separate phases, both using qualitative and quantitative data. In the first phase, a survey was sent to eleven experts asking them to rank the criteria on a scale from less important, to equal, to more important. Since there are relatively few experts available due to the limited size of the wind energy industry, this sample size seemed sufficient for the purpose, that is, to test whether using a MCDA model can improve decision making. Seven experts responded in the course of autumn 2017. Four of them were business developers in wind IPP companies, two worked for companies that focus on increasing IPPs entry into African countries. One did not complete the entire survey so that response was not included in the analysis. Each respondent was required to rank a criterion to another by moving the marker on the scale. The location of the marker correlates to a number, between one and nine, which was then assigned to each answer. This number was then incorporated in the AHP method to determine the weighting of the specific criteria which were used as input into the PROMETHEE model.

The second phase ranked the countries in order of IPP preference for new market entry, based on the quantitative and qualitative criteria, with the weighting determined in the first phase. The specific criteria were identified in the literature reviewed and are highlighted in Table 3 and Figure 2. The criteria data for each country was sourced from public documents, literature reviewed and various websites. The PROMETHEE model was identified as the preferred method to rank the countries based on the criteria. 


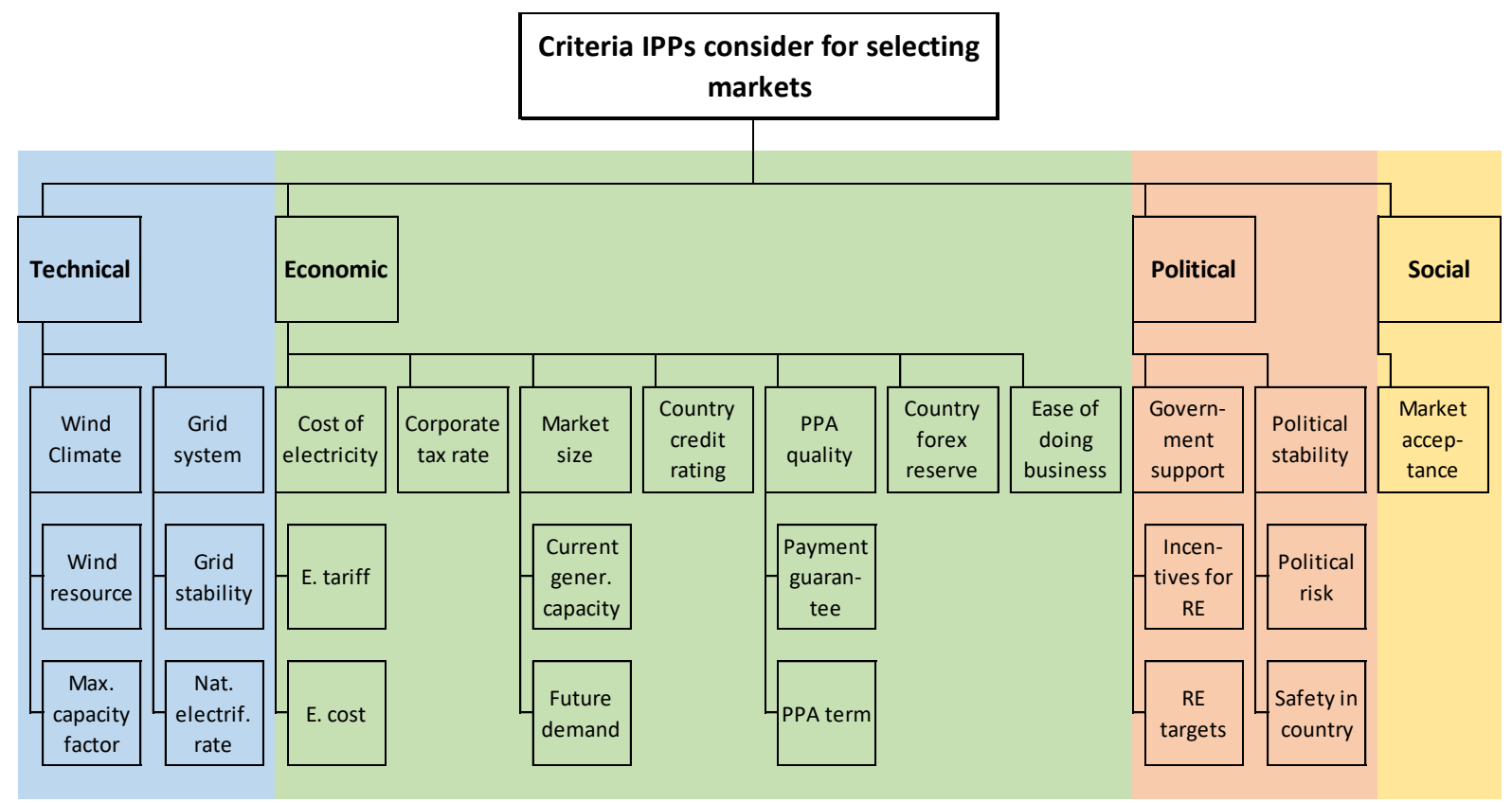

Figure 2: Hierarchy of the research problem of this study

\subsection{Phase One: Ranking the criteria and data collection}

3.2.1 Expert survey

The objective of the survey is to obtain expert market opinion required for the weighting of the criteria using the AHP. The survey was created in Survey Monkey (www.surveymonkey.com) and required approximately fifteen minutes to com-plete. Participants were emailed a covering letter with a link to the survey. It was considered that for this level of research, eleven survey experts, with a response rate of above $50 \%$, was sufficient for the purposes of the research.

\subsubsection{AHP}

The AHP method requires a hierarchy structure to represent the problem (see Figure 2). Level 1 includes the overarching criteria, these being technical, economic, political and social. Level 2 contains the sub-criteria of the overarching criteria, and Level 3 contains the sub-criteria of Level 2 . Next, a pairwise comparison determines the relationship and therefore relative importance of criteria within the structure. Level 1 criteria are pairwise compared to arrange the overarching criteria from most to least important. The outcome is a pairwise comparison matrix of the Level 1 pairwise criteria, shown in Table 4. For example, in row 1, column $2(1,2)$ the relative importance of technical criteria is compared to the importance of economic criteria (T/E). The criteria are scored in terms of the fundamental scale developed by Saaty (1987), shown in Table 5.

For example, if technical criteria are more important than economic criteria, the value in $(1,2)$ will be greater than one (the higher the number, the more important technical criteria are compared to economic criteria). If, however, economic criteria are more important than technical criteria, the value would be the reciprocal, between $1 / 2$ to $1 / 9$ depending on how much more important economic criteria is than technical criteria, where $1 / 2$ would indicate only slightly more important and $1 / 9$ would indicate much more important.

Table 4: Pairwise comparison matrix of the level 1 criteria (adapted from Saaty, 1987: 164)

\begin{tabular}{lcccc}
\hline & Technical & Economic & Political & Social \\
\hline Technical & 1 & $\mathrm{~T} / \mathrm{E}$ & $\mathrm{T} / \mathrm{P}$ & $\mathrm{T} / \mathrm{S}$ \\
Economic & $\mathrm{E} / \mathrm{T}$ & 1 & $\mathrm{E} / \mathrm{P}$ & $\mathrm{E} / \mathrm{S}$ \\
Political & $\mathrm{P} / \mathrm{T}$ & $\mathrm{P} / \mathrm{E}$ & 1 & $\mathrm{P} / \mathrm{S}$ \\
Social & $\mathrm{S} / \mathrm{T}$ & $\mathrm{S} / \mathrm{E}$ & $\mathrm{S} / \mathrm{P}$ & 1 \\
\hline
\end{tabular}

Table 5: Scale used in the pairwise comparison of criteria (Saaty 1987: 163)

\begin{tabular}{|c|c|c|}
\hline Scales & Degree of preference & Explanation \\
\hline 1 & Equally & Two activities contribute equally to the objective \\
\hline 3 & Moderately & $\begin{array}{l}\text { Experience and judgement slightly to moderately favour one activ- } \\
\text { ity over another }\end{array}$ \\
\hline
\end{tabular}




\begin{tabular}{|c|c|c|}
\hline Scales & Degree of preference & Explanation \\
\hline 5 & Strongly & $\begin{array}{l}\text { Experience and judgement strongly or essentially favour one activ- } \\
\text { ity over another }\end{array}$ \\
\hline 7 & Very strongly & $\begin{array}{l}\text { An activity is strongly favoured over another and its dominance is } \\
\text { showed in practice }\end{array}$ \\
\hline 9 & Extremely & $\begin{array}{l}\text { The evidence of favouring one activity over another is of the highest } \\
\text { degree possible of an affirmation }\end{array}$ \\
\hline $2,4,6,8$ & Intermediate values & $\begin{array}{l}\text { Used to represent compromises between the preferences in weights } \\
1,3,5,7 \text { and } 9\end{array}$ \\
\hline Reciprocals & Opposites & Used for inverse comparison \\
\hline
\end{tabular}

The next step is a pairwise comparison for the Level 2 sub-criteria belonging to each Level 1 main criterion, resulting in four additional pairwise matrices. Then the Level 3 sub-criteria under each of the Level 2 sub-criteria are compared, resulting in seven additional pairwise matrices. Note that not all of the Level 2 sub-criteria have criteria below them, and therefore it is seven and not twelve matrices which would have been the case if each Level 2 sub-criterion had more than one criterion below it.

\subsubsection{Consistency in the AHP method}

When using the AHP method it is important to check for consistency and the interpretation of results should take any inconsistencies into account. Normally inconsistencies of approximately less than $10 \%$ are allowed.

The data collected from the expert survey is incorporated into an online AHP Priority Calculator, developed by Goepel (2018), which automatically calculates the weighting of each criterion and the consistency ratio. The online programme address is http://bpmsg.com/ahp-o nline-calculator on the Business Performance Management Singapore website (http://bpmsg.com). The results of the survey (average for each answer) is entered on the website which then calculates the consistency ratio and the weighting of the criteria.

\subsection{Phase Two: Ranking criteria and data collection}

In the second phase the countries are ranked from most to least preferred for IPP market entry. Seven SSA countries are included in the analyses: Ethiopia, Kenya, Mozambique, Namibia, Nigeria, South Africa and Zambia. Seven countries were considered sufficient for the purposes of this research and the countries were selected to incorporate a broad diversity with regards to the criteria used.

The PROMETHEE outranking method is used to rank the countries in order of preference. The PROMETHEE I for partial ranking and PROMETHEE II for complete ranking was developed by Brans (1982). Various versions of PROMETHEE have since been developed. There are two defining steps in the PROMETHEE model: first, selecting the weighting of the criteria, and, secondly, selecting the preference function for each criterion. The weighting was determined in the previous section using an expert survey and the AHP method. Selecting the correct preference function is essential in the PROMETHEE model and deter-mined by specifying the indifference threshold (q) and preference threshold (p). The indifference threshold represents the maximum deviation between two scores that can be considered negligible when comparing two criteria. The preference threshold on the other hand is the minimum deviation between two scores that can be considered significant when comparing two criteria. These preference functions of the criteria shown in Figure 2 are built into the PROMETHEE model. Each of these is discussed in detail in the added supplementary information document to this research article. The PROMETHEE model is run through the visual PROMETHEE version 1.4 software (VP Solutions 2013).

The country forex reserve, payment guarantee and PPA criteria are not included in the PROMETHEE analyses as there is either no data available (payment guarantee and PPA term) or the data is not available for all countries (forex reserve). The criteria were still included in the ranking of criteria as it illustrates their importance which is useful in advising policy makers and governments wishing to procure renewables.

\section{Analysis of data}

\subsection{Phase one: Ranking the criteria}

The results of the expert survey were entered into the online AHP priority calculator, and the weighting, and thus importance, of each criterion was determined. All results met the AHP consistency ratio test and were well under the $10 \%$ cutoff $(1.7 \%$ for level 1 and a maximum of $3.9 \%$ for all level 2 and level 3 criteria). The results for the first level indicate that political criteria are the most important at $39.5 \%$, economic ones second at $36.1 \%$. Technical and social criteria are considerably less important at $13.4 \%$ and $10.7 \%$ (see Table 6). 
Table 6: Criteria ranking results based on the AHP showing the percentage of the total weighting

\begin{tabular}{|c|c|c|c|c|c|}
\hline \multicolumn{2}{|c|}{ Category } & \multicolumn{2}{|l|}{ Criteria } & \multicolumn{2}{|l|}{ Sub-criteria } \\
\hline Technical & $13.4 \%$ & Wind climate & $50.0 \%$ & Wind resource $(0-10)$ & $75.0 \%$ \\
\hline & & & & Max capacity factor $(0-10)$ & $25.0 \%$ \\
\hline & & Grid system & $50.0 \%$ & Grid stability (1-7) & $85.7 \%$ \\
\hline & & & & National electrification rate $(\%)$ & $13.3 \%$ \\
\hline \multirow[t]{10}{*}{ Economic } & $36.1 \%$ & Cost of electricity & $7.7 \%$ & Electricity tariff (c/kWh) & $75.0 \%$ \\
\hline & & & & Electric generation cost $(\mathrm{c} / \mathrm{kWh})$ & $25.0 \%$ \\
\hline & & Corporate tax rate $(\%)$ & $4.9 \%$ & & \\
\hline & & Market size & $17.7 \%$ & Current generation (TWh) & $33.3 \%$ \\
\hline & & & & Future demand (MW/yr) & $66.7 \%$ \\
\hline & & Country credit rating & $19.6 \%$ & & \\
\hline & & PPA quality & $29.0 \%$ & Payment guarantee & $80.0 \%$ \\
\hline & & & & PPA term & $20.0 \%$ \\
\hline & & Country forex reserve & $12.4 \%$ & & \\
\hline & & Ease of doing business & $8.9 \%$ & & \\
\hline \multirow[t]{4}{*}{ Political } & $39.5 \%$ & Government support & $75.0 \%$ & Renewable energy targets & $25.0 \%$ \\
\hline & & & & $\begin{array}{l}\text { Incentives specifically and } \\
\text { exclusively for on-grid renewable } \\
\text { energy }\end{array}$ & $75.0 \%$ \\
\hline & & Political stability & $25.0 \%$ & Political risk & $80.0 \%$ \\
\hline & & & & Safety in country & $20.0 \%$ \\
\hline Social & $10.7 \%$ & Market acceptance & $100.0 \%$ & & \\
\hline
\end{tabular}

\subsection{Phase two: Ranking the countries}

The first step in the country ranking process was to collect the information for the criteria for each country. Various academic and non-academic publications and websites were used to gather the data. Information for each country is given in Table 7 .

\subsection{Country ranking results}

The second step in the process of ranking the countries was to build the PROMETHEE model using the weighting determined in phase 1 along with the data collected for each country for the nineteen criteria. The PROMETHEE model was built in the programme Visual PROMETHEE. This programme auto-changed some of the order of the sub-criteria. Column 4 in Table 7 shows the numerical order of these presented in Figures 3-11 and these are autopopulated from Visual PROMETHEE.

The model showed that South Africa is the most favourable country for wind IPPs, followed by Ethiopia and Namibia. Kenya was fourth, Mozam-bique fifth, Nigeria sixth and Zambia seventh. The results are shown in Figure 3; the top half of the figure illustrates the PROMETHEE ranking and the bottom half shows the weighting of the criteria. The colours correspond to those in Figure 2.

If the weighting is removed and all criteria are considered equally important (see Figure 4), South Africa remains the most attractive market and Zambia the least attractive. Namibia is second, Kenya third and Ethiopia fourth. The least attractive three countries remain unchanged.

\subsection{Individual country results}

An action profile was created for each country, showing which of the criteria contributed positively and which contributed negatively to the country's overall ranking.

\section{South Africa}

South Africa is the top ranked country (Figure 5). The wind climate criteria are significantly positive. Some of the economic and political criteria also contribute positively, with market size, incentives for on-grid renewable energy, credit rating and political risk all notably positive. However, not all criteria are positive: the tariff and generation cost are substantially negative. Ease of doing business, safety in country and market acceptance are also all slightly negative. 
Table 7: Data for the criteria included in this study for each country

\begin{tabular}{|c|c|c|c|c|c|c|c|c|c|c|}
\hline $\begin{array}{l}\text { Cate- } \\
\text { gory }\end{array}$ & Criteria & Sub-criteria & $\begin{array}{c}\text { Auto } \\
\text { order for } \\
\text { Fig. } 4-12\end{array}$ & $\frac{0}{2} \cdot \frac{0}{2}$ & 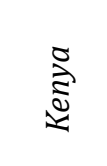 & 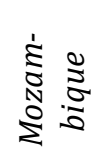 & 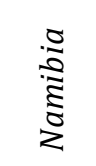 & $\begin{array}{l}\frac{2}{2} \\
\frac{2}{2} \\
0\end{array}$ & 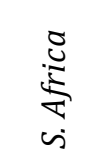 & 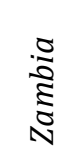 \\
\hline \multirow[t]{4}{*}{$\begin{array}{l}\text { Tech- } \\
\text { nical }\end{array}$} & Wind climate & $\begin{array}{l}\text { Wind resource } \\
(0-10)\end{array}$ & 1 & 6.0 & 6.0 & 1.0 & 1.0 & 0.5 & 10.0 & 5.0 \\
\hline & & $\begin{array}{l}\text { Max capacity factor } \\
(0-10)\end{array}$ & 2 & 9 & 10 & 5 & 7 & 4 & 7 & 4 \\
\hline & Grid system & Grid stability (1-7) & 3 & 3.4 & 3.9 & 2.8 & 5.5 & 1.4 & 3.0 & 2.5 \\
\hline & & $\begin{array}{l}\text { National electrifi- } \\
\text { cation rate }(\%)\end{array}$ & 4 & 24 & 20 & 39 & 13 & 64 & 85 & 26 \\
\hline \multirow[t]{10}{*}{$\begin{array}{l}\text { Econo- } \\
\text { mic }\end{array}$} & $\begin{array}{l}\text { Cost of elec- } \\
\text { tricity }\end{array}$ & $\begin{array}{l}\text { Electricity tariff } \\
(\mathrm{c} / \mathrm{kWh})\end{array}$ & 5 & 5.7 & 17.2 & 6.6 & 13.1 & 4.5 & 4.7 & 3.3 \\
\hline & & $\begin{array}{l}\text { Electric generation } \\
\operatorname{cost}(\mathrm{c} / \mathrm{kWh})\end{array}$ & 6 & 8.5 & 14.2 & 9.0 & 11.3 & 9.7 & 5.0 & 6.5 \\
\hline & $\begin{array}{l}\text { Corporate tax } \\
\text { rate }(\%)\end{array}$ & & 10 & 30 & 30 & 32 & 32 & 30 & 28 & 35 \\
\hline & Market size & $\begin{array}{l}\text { Current generation } \\
\text { (TWh) }\end{array}$ & 7 & 9 & 9 & 16 & 4 & 37 & 227 & 16 \\
\hline & & $\begin{array}{l}\text { Future demand } \\
(\mathrm{MW} / \mathrm{yr})\end{array}$ & 7 & 1.637 & 1.168 & 100 & 90 & 2.051 & 2.727 & 175 \\
\hline & $\begin{array}{l}\text { Country credit } \\
\text { rating }\end{array}$ & & 11 & B & $\mathrm{B}+$ & $\mathrm{CC}$ & BBB- & $\mathrm{B}+$ & $\mathrm{BB}+$ & B \\
\hline & PPA quality & Payment guarantee & & & & & & & & \\
\hline & & PPA term & & & & & & & & \\
\hline & $\begin{array}{l}\text { Country forex } \\
\text { reserve }\end{array}$ & & & & & & & & & \\
\hline & $\begin{array}{l}\text { Ease of doing } \\
\text { business }\end{array}$ & & 12 & 159 & 92 & 137 & 108 & 169 & 74 & 98 \\
\hline \multirow[t]{4}{*}{$\begin{array}{l}\text { Polit- } \\
\text { ical }\end{array}$} & $\begin{array}{l}\text { Government } \\
\text { support }\end{array}$ & $\begin{array}{l}\text { Renewable energy } \\
\text { targets }\end{array}$ & 8 & Yes & Yes & Yes & Yes & Yes & Yes & No \\
\hline & & $\begin{array}{l}\text { Incentives specifi- } \\
\text { cally and exclu- } \\
\text { sively for on-grid } \\
\text { renewable energy }\end{array}$ & 9 & No & No & No & No & No & Yes & \\
\hline & Political stabil- & - Political risk & 13 & -1.48 & 1.29 & -0.58 & 0.59 & -2.13 & -0.18 & 0.15 \\
\hline & ity & Safety in country & 14 & 119 & 131 & 68 & 55 & 149 & 126 & 40 \\
\hline Social & $\begin{array}{l}\text { Market ac- } \\
\text { ceptance }\end{array}$ & & 15 & 9 & 0 & 0 & 0 & 0 & 1 & 0 \\
\hline
\end{tabular}




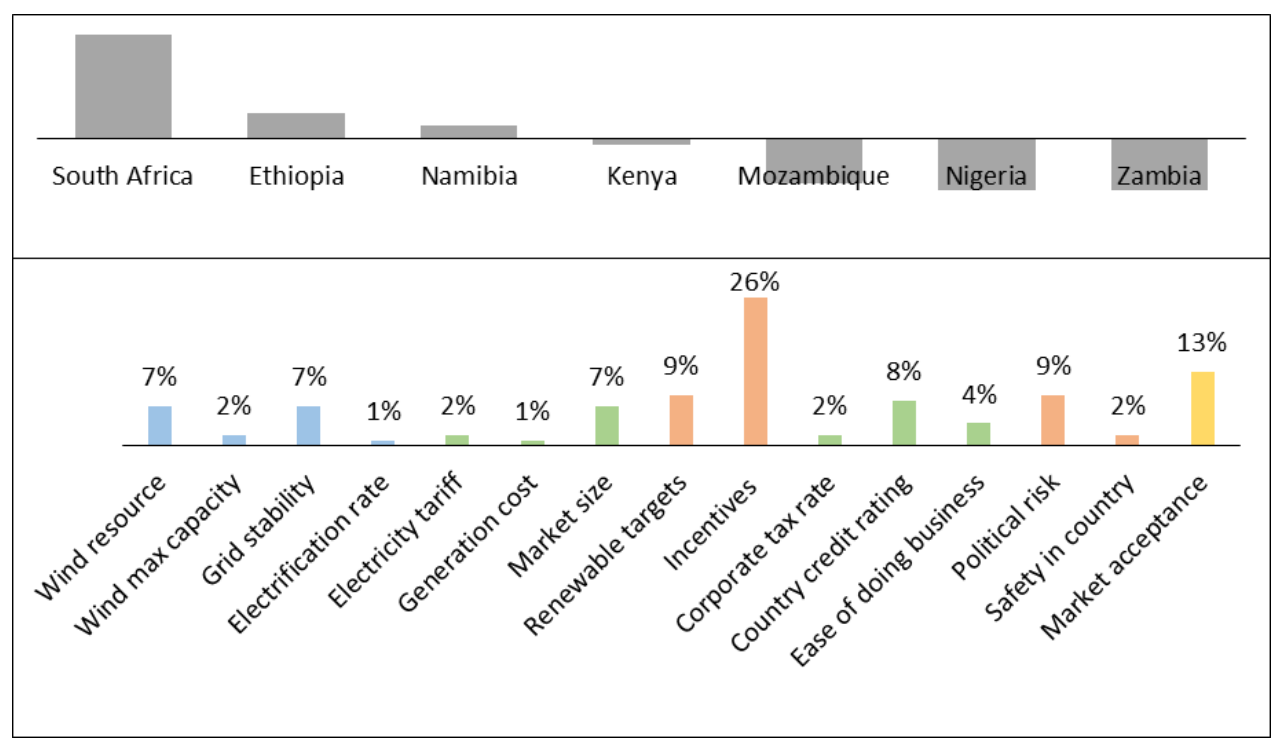

Figure 3: Country ranking from most to least favourable based on sixteen criteria with weights defined for each criterion.

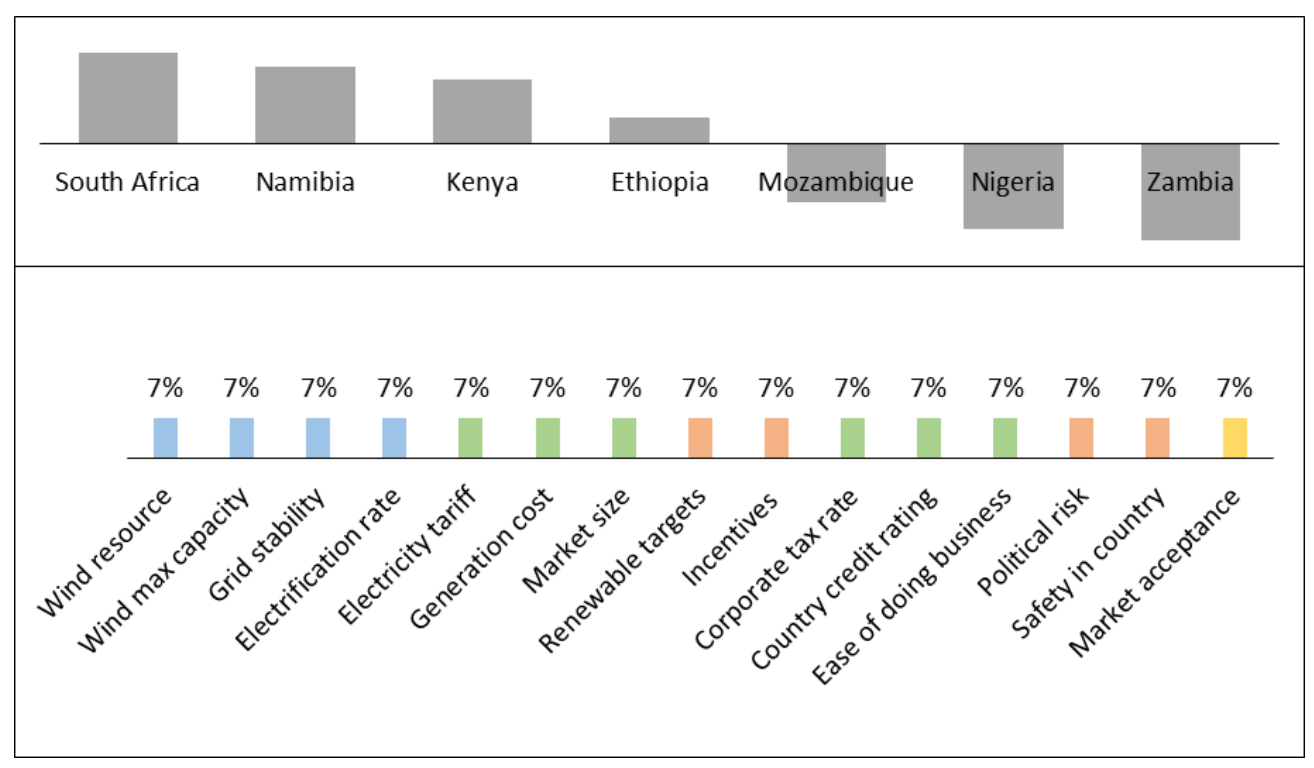

Figure 4: Country ranking from most to least favourable based on the sixteen criteria with equal weights.

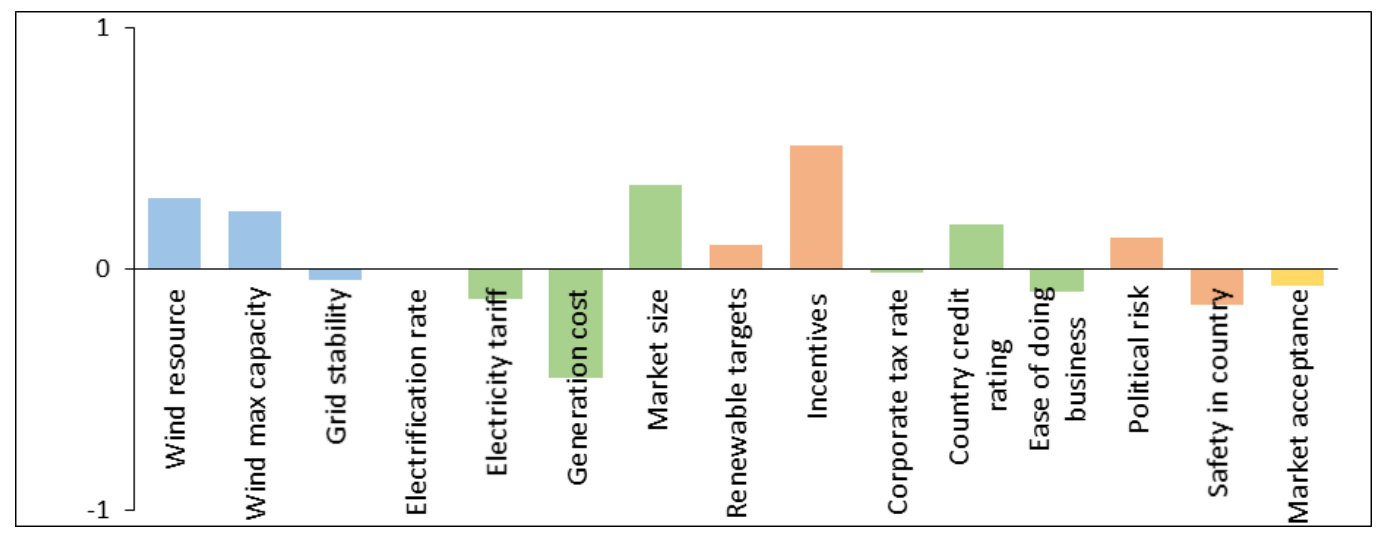

Figure 5: Action profile for South Africa. 


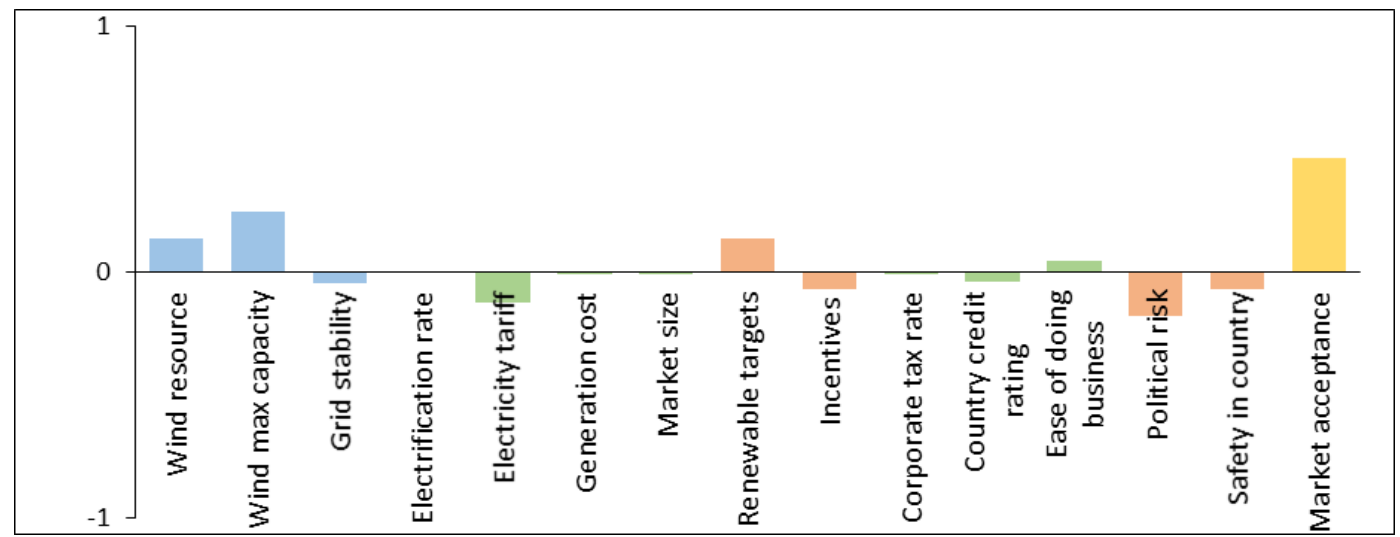

Figure 6: Action profile for Ethiopia.

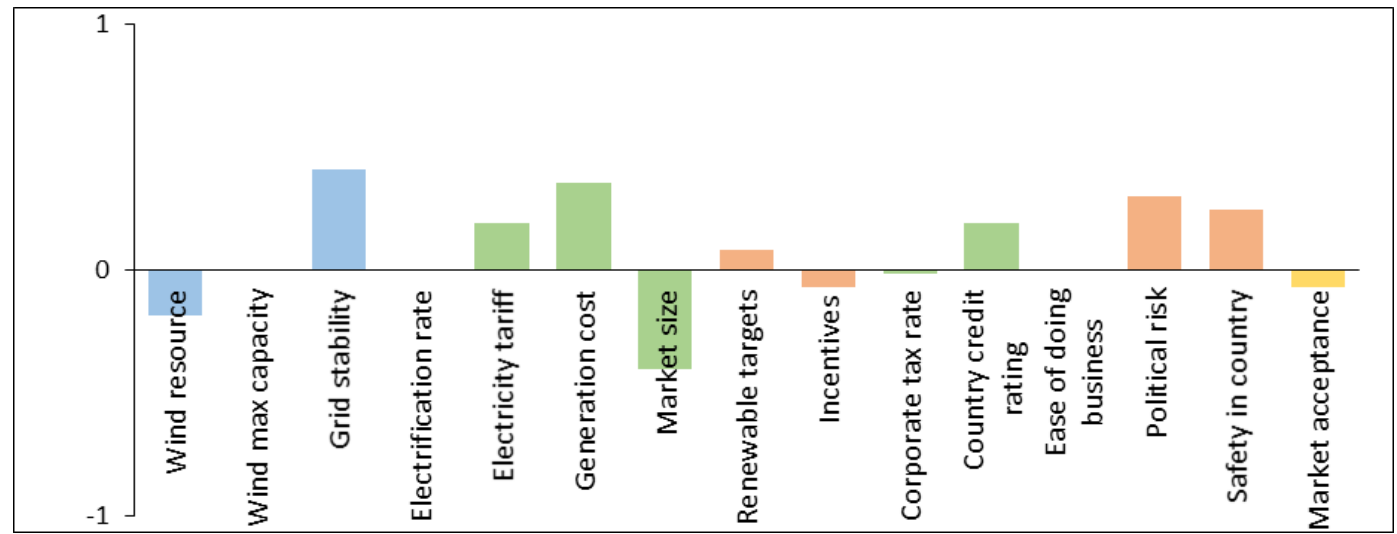

Figure 7: Action profile for Namibia.

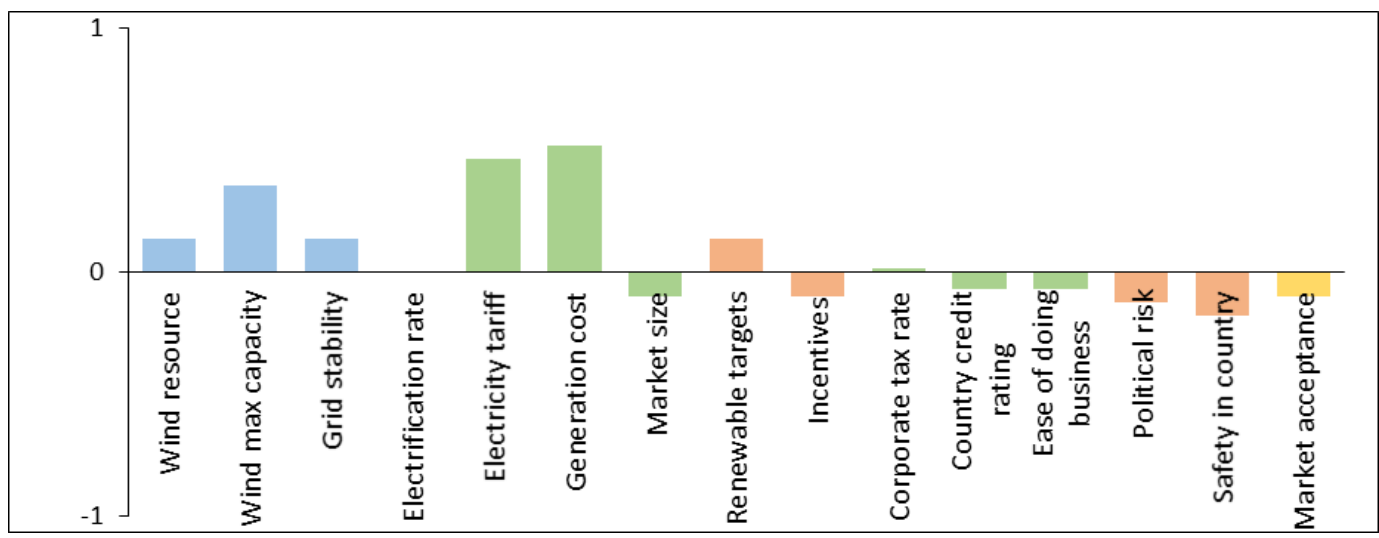

Figure 8: Action profile for Kenya.

Ethiopia

In Ethiopia, the second-ranked country, market acceptance is clearly the biggest positive criterion, followed by the wind climate criterion (Figure 6). The drawbacks are the political criteria, specifically political risk and safety in country, but tariff and incentives for renewable energy are also negative.

\section{Namibia}

Namibia scored highly for many criteria (Figure 7), which is why it secured third place. However, the wind resource, renewable energy incentives and especially the market size held it back.
Kenya

Kenya (Figure 8), scores well in almost all technical criteria, but its main positives are economic criteria namely tariff and generation cost. Kenya is held back by its political and social criteria, which are all mostly negative.

\section{Mozambique}

Mozambique (Figure 9) has few positive criteria, scoring low in all technical, social and economic criteria. The political criteria are the only positives, specifically safety in country and renewable energy targets. 


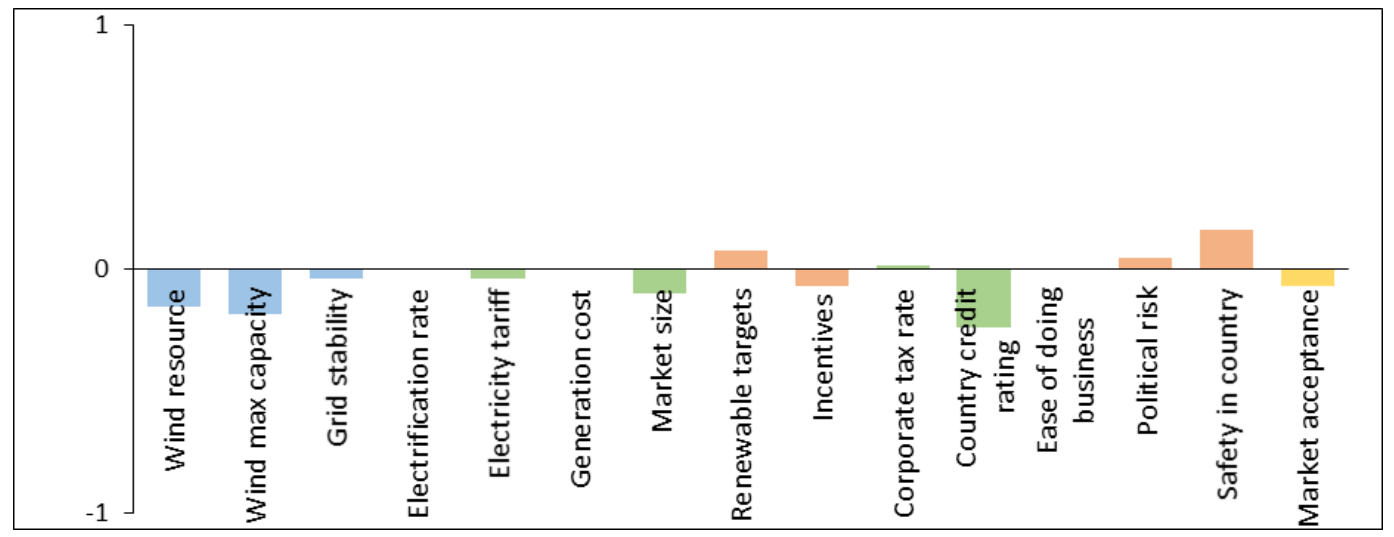

Figure 9: Action profile for Mozambique

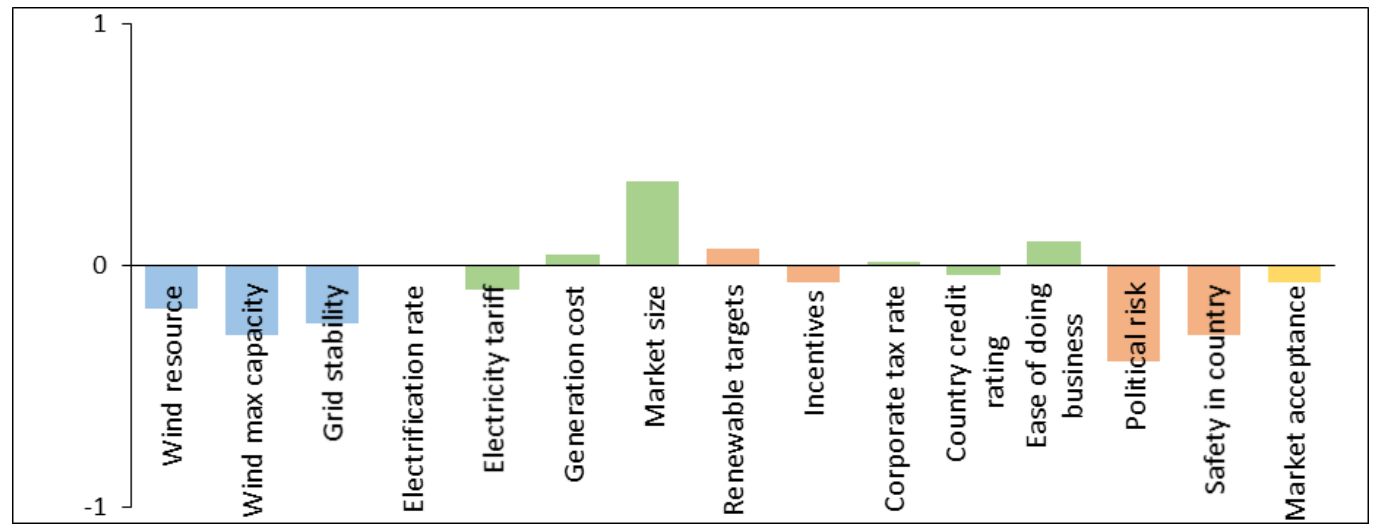

Figure 10: Action profile for Nigeria

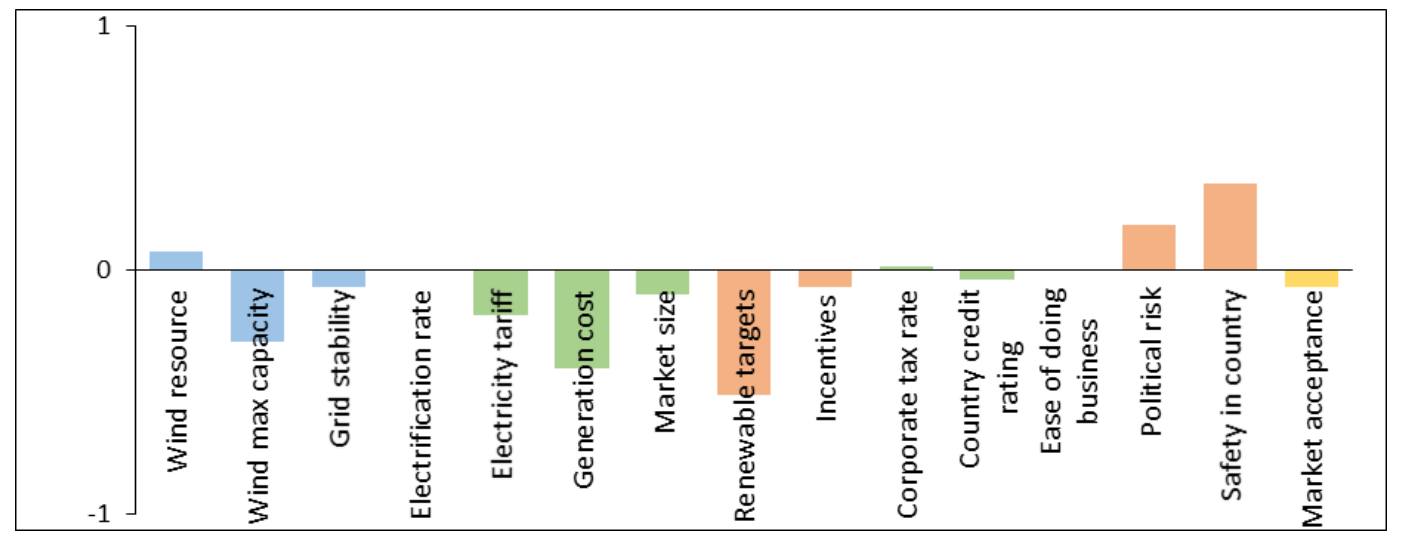

Figure 11: Action profile for Zambia

\section{Nigeria}

Nigeria (Figure 10) is the sixth-ranked country with all technical and most political data scoring significantly negative. The most positive criterion is market size, second only to South Africa. Other positive criteria include ease of doing business, cost of electricity, and renewable energy targets.

Zambia

Zambia (Figure 11) is the lowest ranked country of the seven considered, with only political risk, safety in country and limited wind resource adding to a positive score. All other criteria are negative, especially the economic criteria.

\section{Discussion}

\subsection{Criteria used in the study}

Seventeen of the nineteen criteria used in this study were selected based on previous research. The two criteria for PPA quality were included for the first time. These criteria were weighted with regards to their importance using the expert survey and the AHP. The weighted criteria were then incorporated into the PROMETHEE model.

Political and economic criteria were considered significantly more important, accounting for a resultant weighting of $76 \%$ overall, while technical and social criteria accounted for the remaining $24 \%$. This is an indication to governments in SSA that if 
they are committed to attracting IPPs to their country, they should focus on improving the economic and political landscape. Governments do have the power and ability to change both the political and economic climate. However, technical criteria, such as wind climate, is out of government control, and accounts for only $13.4 \%$ weighting. Governments also do not control market acceptance, while they can attempt to improve it. This accounts for only $10.7 \%$ weighting. Govern-ments are therefore in a position to change a country's attractiveness for IPPs, as they can improve the criteria which account for $76 \%$ of the successful impact.

Within the political criteria, government support through incentives specifically and exclusively for on-grid renewable energy will go a long way to increase market attractiveness. Examples of incentives used internationally include tax exemptions, accelerated depreciation, financial subsidies, credit facilities and third party financing mechanisms (Painuly, 2001). Incentives could also be indirect, for example compelling utilities to buy 'green' energy (Menanteau et al., 2003). Also important under the political criteria is political risk, and this is in the hands of governments to manage. Governments can improve the situation, for example, by ensuring government stability, reducing internal conflict and ethnic friction, ensuring basic democratic rights, and ensuring law and order through a strong and independent legal system (Perotti and Van Oijen, 2001; Busse and Hefeker, 2007).

Within economic criteria the PPA quality and the country credit rating are the two most important criteria at $29.0 \%$ and $19.6 \%$ weightings. This justifies the PPA quality criterion being included in the analyses and it is recommended that all future studies involving IPPs should include PPA criteria. Providing a PPA payment guarantee is complex, as there is a trade-off which the government will need to consider. While a PPA payment guarantee will make the market more attractive for IPPs, it also increases a country's fiscal risk (Cangiano et al., 2006). An improved country credit rating is beneficial for all parties and influences the debt financing available to projects (Chowdhury and Charoenngam, 2009). At the time of this study, most countries in Africa, and all but one in this study, had sub-investment grade ratings. Improving the credit rating will directly improve the economic environment and allow IPPs better financing terms to develop power projects, which will also translate into lower tariffs. If the country is sub-investment grade, however, it would need multiple agreements and guarantees to make a project attractive (Chowdhury and Charoenngam, 2009). Also important under economic criteria is market size, which was weighted $17.7 \%$. Countries with small populations will find it hard to compete with the larger countries that will naturally have a higher demand for power.

\subsection{Results comparison with other studies}

The results of this study can be compared with the results of Wijnja (2014), Nganga and Maruyama (2015), and Beim and Lévesque (2006). Although not all the same countries were included in the studies and different methods were used for the ranking, these are the most applicable studies to compare with.

The results are not uniform across the four studies (including the present one); in fact, the country ranking varies significantly. This can be explained by a number of differences. Firstly, the different objectives of the studies. Not all of them focus on renewable energy. Secondly, the different criteria, for example adding infrastructure criteria and different sub-criteria. Thirdly, the difference in weighting of criteria, and, lastly, the methods used for the ranking (SWOT, AHP, PROMETHEE). There is, however, a single consistent result and that is that, in all the studies, South Africa was considered more attractive than the other six countries considered here.

By providing a methodology that is specifically designed for the wind IPP's selection process, the study helps to close the gap in the literature between the work on (renewable) energy in general, the management of IPPs, and applied decision theory.

\section{Conclusions}

The aim of this study was to determine, assess and rank the most important criteria that wind IPPs should consider when evaluating market entry. By using an analytical and more formal decision making process, such as MCDA, and using these ranked criteria to determine which selected countries in SSA are most favourable for wind IPPs, these will significantly help to reduce market entry risk. This research will assist IPPs that specialise in wind energy and need to evaluate new markets for entry into SSA.

This study showed that, by using MCDA methods such as AHP and PROMETHEE, a decision maker has the ability to include opinions of different experts and professionals in the industry. Different and numerous informed opinions will result in a better-informed decision, one that can be justified. MCDA methods also allow the decision maker to remove personal biases when making a decision, thereby making it objective. Having an objective and better-informed decision is likely to lead to a more successful outcome.

One of the difficulties of using MCDA methods is to convince the various stakeholders of their usefulness. Although (or because?) AHP and PROMETHEE are very logical instruments, some people tend to 
disapprove of this kind of problem solving-at least this is our experience from consulting projects, which is consistent with some of the (scarce) literature in this field (see, for example, Aloysius et al., 2006). Therefore it is essential for an IPP to ensure acceptance among its staff and shareholders. Furthermore, the application of this methodology is not a one-time exercise. As political, economic and other conditions change over time, it is important to regularly feed the models with new data, analyse the changes and adapt the strategy accordingly.

On the side of the policy makers, this study can be used to attract more IPPs. Some factors such as the country rating are hard to change, others are easier because they are within the responsibility of the government. Key levers according to this study are the political and economic factors that create a favourable investment climate, reliable energy targets, incentives, payment guarantees and tariffs. Some of them may be costly, but - as always in sustainability issues - in the long run the measures will be much cheaper than not developing renewable energies and continuing to use fossilefuel.

The objectives resulting from the research aim were all achieved. The criteria wind IPPs currently consider when evaluating new markets were collected from the literature. Then the criteria were ranked based on an expert survey and the AHP. After that a data analysis showed the performance of all countries regarding these criteria, so that a country ranking could be determined. This made it possible to come to certain conclusions for countries to create a more favourable environment for wind IPPs. Future research can use and adapt this study to not only compare countries, but also states or provinces within countries, and even sites within one area. For example, Nigeria's political situation differs dramatically between the different states. Some of the states could be very favourable while others should best be avoided. On the site level, this methodology could improve the tedious search process for wind farms; it contains more rational and transparent steps than a single AHP model such as the one described by Höfer et al. (2016) and, thus, could possibly help to reduce social conflicts.

A completely different aspect for future research is how the method could be extended to include insights from behavioural economics, especially behavioural operational research. MCDA is a typical neoclassical approach which has its shortcomings when the 'human factor' plays an important role in decision making. This article has not addressed this issue, but the important decision to invest in a particular country remains a human decision, made by a wind IPP's executive board. Traditional MCDA models help to come to a decision, but they do not correct human biases, overcome cognitive limits, offset differences in education or in other ways take the decision maker into account.

The methods used in this study are not restricted to the wind industry and can be expanded to different technologies and industries to assist with decision making in difficult scenarios.

\section{Author roles}

Lausberg: Decision theory and decision support systems; proofreading and revisions; tables and figures.

Evans: Thesis supervision; first and second draft; submission and organisation.

De Jongh: Thesis, complete with formulation of goals and research design, literature review, empirical survey, analysis, documentation of results, references, tables and figures.

\section{Acknowledgements:}

This paper is based on work undertaken by Enelge De Jongh (née Gildenhuys), submitted in partial fulfilment of the requirements of the degree of MSc in Property Studies at the University of Cape Town, South Africa. The authors would like to thank the two anonymous referees and the editors for their helpful comments.

\section{References}

Afsordegan, A., Sánchez, M., Agell, N., Zahedi, S. \& Cremades, L. 2016. Decision making under uncertainty using a qualitative TOPSIS method for selecting sustainable energy alternatives. International Journal of Environmental Science and Technology, 13 (6), 1419-1432.

Alova, G., Trotter P. A. \& Money, A. 2021. A machine-learning approach to predicting Africa's electricity mix based on planned power plants and their chances of success. Nature Energy, 6 (2), 158-166.

Aloysius, John A., Davis, Fred D., Wilson, Darryl D., Taylor, A. Ross \& Kottemann, Jeffrey E. 2006. User acceptance of multi-criteria decision support systems: The impact of preference elicitation techniqu es. European Journal of Operational Research, 169 (1), 273-285.

Bazilian, M., Nussbaumer, P., Rogner, H.-H., Brew-Hammond, A., Foster, V., Pachauri, S., Williams, E., Howells, M., Niyongabo, P. \& Musaba, L. 2012. Energy access scenarios to 2030 for the power sector in sub-Saharan Africa. Utilities Policy, 20 (1), 1-16.

Beck, F. \& Martinot, E. 2004. Renewable energy policies and barriers. In Cutler J Cleveland (Ed.), Encyclopedia of Energy, 365-383. New York: Elsevier.

Beim, G. \& Lévesque, M. 2006. Country selection for new business venturing: A multiple criteria decision analysis. Long Range Planning, 39 (3), 265-293.

Brans, J.-P. \& Vincke, P. 1985. Note - A preference ranking organisation method: (The PROMETHEE method for multiple criteria decision-making). Management Science, 31 (6), 647-656. 
Brans, J. 1982. L'ingénierie de la décision: l'elaboration d'instruments d'aide à la decision, Colloque sur l'aide à la decision. Faculté des Sciences de l'Administration, Université Laval, CAN.

Brew-Hammond, A. 2010. Energy access in Africa: Challenges ahead. Energy Policy, 38 (5), 2291-2301.

Busse, M. \& Hefeker, C. 2007. Political risk, institutions and foreign direct investment. European Journal of Political Economy, 23 (2), 397-415.

Cangiano, M., Alier, M., Anderson, B., Hemming, R. \& Petrie, M. 2006. Public-private partnerships, government guarantees, and fiscal risk. International Monetary Fund, Washington D.C., USA.

Celiktas, M. S. \& Kocar, G. 2010. From potential forecast to foresight of Turkey's renewable energy with Delphiapproach. Energy, 35 (5), 1973-1980.

Chen, W.-M., Kim, H. \& Yamaguchi, H. 2014. Renewable energy in eastern Asia: Renewable energy policy review and comparative SWOT analysis for promoting renewable energy in Japan, South Korea, and Taiwan. Energy Policy, 74, 319-329.

Cheng, M.-Y., Tsai, H.-C. \& Chuang, K.-H. 2011. Supporting international entry decisions for construction firms using fuzzy preference relations and cumulative prospect theory. Expert Systems with Applications, 38 (12), 1515115158.

Chowdhury, A. N. \& Charoenngam, C. 2009. Factors influencing finance on IPP projects in Asia: A legal framework to reach the goal. International Journal of Project Management, 27 (1), 51-58.

Deichmann, U., Meisner, C., Murray, S. \& Wheeler, D. 2011. The economics of renewable energy expansion in rural subSaharan Africa. Energy Policy, 39 (1), 215-227.

Diakoulaki, D. \& Karangelis, F. 2007. Multi-criteria decision analysis and cost-benefit analysis of alternative scenarios for the power generation sector in Greece. Renewable and Sustainable Energy Reviews, 11 (4), 716-727.

Eberhard, A., Foster, V., Briceño-Garmendia, C., Ouedraogo, F., Camos, D. \& Shkaratan, M. 2008. Underpowered: the state of the power sector in sub-Saharan Africa. Background paper, 6. The World Bank Washington D.C., USA.

Eberhard, A. \& Gratwick, K. N. 2011. IPPs in sub-Saharan Africa: determinants of success. Energy Policy, 39 (9), 5541 5549.

Eggoh, J. C., Bangaké, C. \& Rault, C. 2011. Energy consumption and economic growth revisited in African countries. Energy Policy, 39 (11), 7408-7421.

Ghobadi, M. \& Ahmadipari, M. 2018. Environmental planning for wind power plant site selection using a fuzzy PROMETHEE-based outranking method in geographical information system. Environmental Energy And Economic Research, 2 (2), 75-87.

Goepel, K. D. 2018. Implementation of an Online Software Tool for the Analytic Hierarchy Process (AHP-OS). International Journal of the Analytic Hierarchy Process, 10 (3), 469-487.

Gokmenoglu, K. \& Alaghemand, S. 2015. A multi-criteria decision-making model for evaluating priorities for foreign direct investment. Croatian Operational Research Review, 6 (2), 489-510.

Gordon, T. J. 1994. The Delphi method: Futures research methodology, Millennium Project, American Council for the United Nations University, Washington D.C., USA.

Höfer, T., Sunak, Y., Siddique, H. \& Madlener, R. 2016. Wind farm siting using a spatial Analytic Hierarchy Process approach: A case study of the Städteregion Aachen. Applied Energy, 163 (1), 222-243.

IEA 2014. Africa Energy Outlook: A focus on energy prospects in sub-Saharan Africa. International Energy Agency, Paris, F.

IEA 2016. Tracking clean energy progress. International Energy Agency, Paris, F.

IEA 2019. Africa Energy Outlook: World Energy Outlook Special Report. International Energy Agency, Paris, F.

IRENA 2021. Renewable Power Generation Costs in 2020. International Renewable Energy Agency, Abu Dhabi, UAE.

Karekezi, S. 2002. Poverty and energy in Africa-a brief review. Energy Policy, 30 (11-12), 915-919.

Lee, A. H., Chen, H. H. \& Kang, H.-Y. 2009. Multi-criteria decision making on strategic selection of wind farms. Renewable Energy, 34 (1), 120-126.

Markovska, N., Taseska, V. \& Pop-Jordanov, J. 2009. SWOT analyses of the national energy sector for sustainable energy development. Energy, 34 (6), 752-756.

Martinot, E., Chaurey, A., Lew, D., Moreira, J. R. \& Wamukonya, N. 2002. Renewable energy markets in developing countries. Annual Review of Energy and the Environment, 27 (1), 309-348.

Mekking, R. 2008. International growth ambition: a country selection and market entry advice for HowTech BV. University of Twente, NL.

Menanteau, P., Finon, D. \& Lamy, M.-L. 2003. Prices versus quantities: choosing policies for promoting the development of renewable energy. Energy policy, 31 (8), 799-812.

Moran, D. \& Sherrington, C. 2007. An economic assessment of windfarm power generation in Scotland including externalities. Energy Policy, 35 (5), 2811-2825.

Murray, T. J. 1979. Delphi methodologies: A review and critique. Urban Systems, 4 (2), 153-158.

Naicker, P. \& Thopil, G. A. 2019. A framework for sustainable utility scale renewable energy selection in South Africa. Journal of Cleaner Production, 224, 637-650. 
Nganga, P. S. \& Maruyama, Y. 2015. Market Attractiveness evaluation of sub-Saharan Africa, Applying SWOT analysis and AHP methods. Journal of Economics and Economic Education Research, 16 (1), 1-18.

Painuly, J. P. 2001. Barriers to ren ewable energy pen etration; a framework for analysis. Renewable Energy, 24 (1), 73 89.

Perotti, E. C. \& Van Oijen, P. 2001. Privatization, political risk and stock market development in emerging economies. Journal of International Money and Finance, 20 (1), 43-69.

Pill, J. 1971. The Delphi method: substance, context, a critique and an annotated bibliography. Socio-Economic Planning Sciences, 5 (1), 57-71.

Pohekar, S. \& Ramachandran, M. 2004. Application of multi-criteria decision making to sustainable energy planning-a review. Renewable and Sustainable Energy Reviews, 8 (4), 365-381.

Polatidis, H., Haralambopoulos, D. A., Munda, G. \& Vreeker, R. 2006. Selecting an appropriate multi-criteria decision analysis technique for renewable energy planning, Energy Sources, Part B: Economics, Planning and Policy 1 (2), 181-193.

Saaty, R. W. 1987. The analytic hierarchy process-what it is and how it is used. Mathematical Modelling, 9 (3-5), 161176.

Snyder, B. \& Kaiser, M. J. 2009. Ecological and economic cost-benefit analysis of offshore wind energy. Renewable Energy, 34 (6), 1567-1578.

Steffen, B., Matsuo, T., Steinemann, D. \& Schmidt, T. S. 2018. Opening new markets for clean energy: The role of project developers in the global diffusion of renewable energy technologies. Business and Politics, 20 (4), 553-587.

Suberu, M. Y., Mustafa, M. W., Bashir, N., Muhamad, N. A.\& Mokhtar, A. S. 2013. Power sector renewable energy integration for expanding access to electricity in sub-Saharan Africa. Renewable and Sustainable Energy Reviews, 25 (1), 630-642.

Swoboda, B., Schwarz, S. \& Hälsig, F. 2007. Towards a conceptual model of country market selection: Selection processes of retailers and C\&C wholesalers. International Review of Retail, Distribution and Consumer Research, 17 (3), 253-282.

Taha, R. A. \& Daim, T. 2013. Multi-criteria applications in renewable energy analysis, a literature review. Research and Technology Management in the Electricity Industry, 17-30, Springer, London, GB.

Terrados, J., Almonacid, G. \& Hontoria, L. 2007. Regional energy planning through SWOT analysis and strategic planning tools: Impact on renewables development. Renewable and Sustainable Energy Reviews, 11 (6), 1275-1287.

Tichy, G. 2004. The over-optimism among experts in assessment and foresight. Technological Forecasting and Social Change, 71 (4), 341-363.

Trotter, P. A., McManus, M. C. \& Maconachie, R. 2017. Electricity planning and implementation in sub-Saharan Africa: A systematic review. Renewable and Sustainable Energy Reviews, 74, 1189-1209.

Varho, V., Rikkonen, P. \& Rasi, S. 2016. Futures of distributed small-scale renewable energy in Finland-A Delphi study of the opportunities and obstacles up to 2025. Technological Forecasting and Social Change, 104, 30-37.

VPSolutions 2013. Visual PROMETHEE. 1.4 ed. www.promethee-gaia.net.

Wang, J.-J., Jing, Y.-Y., Zhang, C.-F. \& Zhao, J.-H. 2009. Review on multi-criteria decision analysis aid in sustainable energy decision-making. Renewable and Sustainable Energy Reviews, 13 (9), 2263-2278.

Wang, Q. \& Poh, K. 2014. A survey of integrated decision analysis in energy and environmental modelling. Energy, 77, 691-702.

Wątróbskia, J., Jankowskib, J., Ziembaa, P., Karczmarczykb, A. \&Zioło, M. 2019. Generalised framework for multi-criteria method selection. Omega, 86, 107-124.

Welty, G. 1972. Problems of selecting experts for Delphi exercises. Academy of ManagementJournal, 15 (1), 121-124.

Wijnja, J. 2014. Global opportunities for airborne wind. Delft University of Technology, NL.

Wu, Y., Tao, Y., Zhang, B., Wang, S., Xu, C. \& Zhou, J. 2020. A decision framework of offshore wind power station site selection using a PROMETHEE method under intuitionistic fuzzy environment: A case in China. Ocean \& Coastal Management, 184, 105016.

WWEA 2018. Identifying success factors for wind power. Analysis of policies and capacities in major European markets: Denmark, Germany, The Netherlands, Spain and United Kingdom. World Wind Energy Association, Bonn, GER. 